\title{
Bromine Isotope Variations in Magmatic and Hydrothermal Sodalite and Tugtupite and the Estimation of Br Isotope Fractionation between Melt and Sodalite
}

\author{
Hans G. M. Eggenkamp ${ }^{1, * \mathbb{D}}$, Michael A. W. Marks ${ }^{1}$, Pascale Louvat $^{2}$ and Gregor Mark1 $^{1}$ \\ 1 Department of Geosciences, Eberhard-Karls-Universität Tübingen, Schnarrenbergstraße 94-96, \\ D-72076 Tübingen, Germany; michael.marks@uni-tuebingen.de (M.A.W.M.); markl@uni-tuebingen.de (G.M.) \\ 2 Institut de Physique du Globe de Paris, Université de Paris, CNRS, F-75005 Paris, France; louvat@ipgp.fr \\ * Correspondence: hans@eggenkamp.info
}

check for updates

Citation: Eggenkamp, H.G.M.; Marks, M.A.W.; Louvat, P.; Markl, G. Bromine Isotope Variations in Magmatic and Hydrothermal Sodalite and Tugtupite and the Estimation of Br Isotope Fractionation between Melt and Sodalite. Minerals 2021, 11, 370. https://doi.org/ $10.3390 / \min 11040370$

Academic Editor: Paolo Censi

Received: 9 February 2021

Accepted: 30 March 2021

Published: 31 March 2021

Publisher's Note: MDPI stays neutral with regard to jurisdictional claims in published maps and institutional affiliations.

Copyright: (c) 2021 by the authors. Licensee MDPI, Basel, Switzerland. This article is an open access article distributed under the terms and conditions of the Creative Commons Attribution (CC BY) license (https:// creativecommons.org/licenses/by/ $4.0 /)$.

\begin{abstract}
We determined the bromine isotope compositions of magmatic and hydrothermal sodalite $\left(\mathrm{Na}_{8} \mathrm{Al}_{6} \mathrm{Si}_{6} \mathrm{O}_{24} \mathrm{Cl}_{2}\right)$ and tugtupite $\left(\mathrm{Na}_{8} \mathrm{Al}_{2} \mathrm{Be}_{2} \mathrm{Si}_{8} \mathrm{O}_{24} \mathrm{Cl}_{2}\right)$ from the Ilímaussaq intrusion in South Greenland, in order to constrain the $\mathrm{Br}$ isotope composition of the melt and hydrothermal fluids from which these minerals were formed. Early formed magmatic sodalite has high $\mathrm{Br}$ contents $(138 \pm 10 \mu \mathrm{g} / \mathrm{g}, \mathrm{n}=5)$ and low $\delta^{81} \mathrm{Br}$ values $(+0.23 \pm 0.07 \%$ o). Late stage hydrothermal sodalite has lower $\mathrm{Br}$ contents $(53 \pm 10 \mu \mathrm{g} / \mathrm{g}, \mathrm{n}=5)$ and higher $\delta^{81} \mathrm{Br}$ values $(+0.36 \pm 0.08 \%$ ). Tugtupite that forms at even later stages shows the lowest $\mathrm{Br}$ contents $(26 \pm 2 \mu \mathrm{g} / \mathrm{g}, \mathrm{n}=2)$ and the highest $\delta^{81} \mathrm{Br}$ values $(+0.71 \pm 0.17 \%$ ). One hydrothermal sodalite has a Br concentration of $48 \pm 9 \mu \mathrm{g} / \mathrm{g}$ and an exceptionally high $\delta^{81} \mathrm{Br}$ of $0.82 \pm 0.12 \%$, very similar to the $\delta^{81} \mathrm{Br}$ of tugtupites. We suggest that this may be a very late stage sodalite that possibly formed under Be deficient conditions. The data set suggests that sodalite crystallises with a negative $\mathrm{Br}$ isotope fractionation factor, which means that the sodalite has a more negative $\delta^{81} \mathrm{Br}$ than the melt, of -0.3 to $-0.4 \%$ from the melt. This leads to a value of +0.5 to $+0.6 \%$ relative to $\mathrm{SMOB}$ for the melt from which sodalite crystallises. This value is similar to a recently published $\delta^{81} \mathrm{Br}$ value of $+0.7 \%$ or very deep geothermal fluids with very high $\mathrm{R} / \mathrm{Ra}$ He isotope ratios, presumably derived from the mantle. During crystallisation of later stage hydrothermal sodalite and the Be mineral tugtupite, $\delta^{81} \mathrm{Br}$ of the residual fluids (both melt and hydrothermal fluid) increases as light ${ }^{79} \mathrm{Br}$ crystallises in the sodalite and tugtupite. This results in increasing $\delta^{81} \mathrm{Br}$ values of later stage minerals that crystallise with comparable fractionation factors from a fluid with increasingly higher $\delta^{81} \mathrm{Br}$ values.
\end{abstract}

Keywords: bromine isotopes; sodalite; tugtupite; isotope fractionation

\section{Introduction}

Since the development of techniques to measure stable bromine $(\mathrm{Br})$ isotopes in geological systems [1], our knowledge on $\mathrm{Br}$ isotope systematics has increased significantly. Our knowledge is currently mostly restricted to aqueous systems and salt deposits and to some environmentally relevant organobromine systems that are Br-rich, and where $\mathrm{Br}$ can easily be extracted in sufficient quantities for isotope analyses [2]. Depending on the analytical technique either about $1 \mathrm{mg}$ (isotope ratio mass spectrometry (IRMS) [1,3]) or $25 \mu \mathrm{g}$ (multi collector inductively coupled plasma mass spectrometry (MC-ICP-MS) [4,5]) of $\mathrm{Br}$ is necessary for a reliable measurement. The large amount of $\mathrm{Br}$ necessary for isotope analysis has, until now, prevented the measurement of $\mathrm{Br}$ isotopes in rock samples.

Bromine has two stable isotopes, ${ }^{79} \mathrm{Br}$ and ${ }^{81} \mathrm{Br}$, which are about equally abundant. Variations in the ratio of these isotopes are reported as $\delta^{81} \mathrm{Br}$ which is defined as [6]:

$$
\delta=\left(\frac{\mathrm{R}_{\text {sample }}}{\mathrm{R}_{\text {standard }}}-1\right) \times 1000
$$


In this equation, $\delta$ stands for $\delta^{81} \mathrm{Br}, \mathrm{R}_{\text {sample }}$ for the ${ }^{81} \mathrm{Br} /{ }^{79} \mathrm{Br}$ ratio of the unknown sample, and $\mathrm{R}_{\text {standard }}$ for the ${ }^{81} \mathrm{Br} /{ }^{79} \mathrm{Br}$ ratio of the international reference standard. In the case of $\mathrm{Br}$, the international reference standard is ocean bromide, abbreviated as standard mean oceanic bromide (SMOB). The oceans are a well-mixed reservoir of bromide and it has been shown [7] that isotope variations between samples taken from various locations are less than the error of measurement as is the case for $\mathrm{Cl}$ [8], where the international standard is ocean chloride, abbreviated as standard mean oceanic chloride (SMOC) [9].

Bromine isotope variations in groundwater and evaporite samples suggest that they are relatively small. Data published prior to 2014 showed that most $\delta^{81} \mathrm{Br}$ values are between -0.5 and $+2.0 \%$ [ [2] and more recent studies extended that range to between -1.5 and $+3.35 \%$ o $[10]$.

In a recent study, an attempt was made to estimate both the $\mathrm{Cl}$ and the $\mathrm{Br}$ isotope composition of the mantle [11]. Based on the ${ }^{3} \mathrm{He} /{ }^{4} \mathrm{He}$ ratios of geothermal water from Mexico, Pinti et al. [11] selected samples with a mantle origin (highest ${ }^{3} \mathrm{He} /{ }^{4} \mathrm{He}$ ) and observed relatively high $\delta^{37} \mathrm{Cl}$ and $\delta^{81} \mathrm{Br}$ values in these geothermal waters. Their conclusion, based on an observed R/Ra of about 8 for the most ${ }^{3} \mathrm{He}$ rich samples, was that both $\mathrm{Br}$ and $\mathrm{Cl}$ isotope values of the upper (depleted) mantle are relatively heavy with respect to modern ocean bromide and chloride at $+0.7-+0.9 \%$. For $\mathrm{Cl}$, this value is higher than previous estimations based on measurements of $\mathrm{Cl}$ isotopes in Mid Oceanic Ridge Basalt (MORB) samples. The older data suggested that $\delta^{37} \mathrm{Cl}$ values of the depleted mantle can vary between -3 and $+0.5 \%$ [12-17], although the generally accepted value for the depleted mantle is $-0.2 \pm 0.3 \%$ [13]. $\mathrm{Cl}$ isotope data from other mantle reservoirs, for example, sampled at Ocean Island Basalts, suggest that $\mathrm{Cl}$ isotope values can be as high as $+3 \%$ [16]. Overall, these observations show that ${ }^{37} \mathrm{Cl}$ in mantle material is highly variable and it is important to understand from what mantle source samples are taken. Based on their data, Pinti et al. [11] suggested a $8^{37} \mathrm{Cl}$ of about $+3 \%$ in the primitive mantle, which is in line with observations by John et al. [16] from Ocean Island Basalts. Although John et al. [16] suggested that these high $\delta^{37} \mathrm{Cl}$ values resulted from crustal contamination by isotopically heavier halogens from subduction slab metasediments, Pinti et al. [11] suggest as alternative interpretation that the lower mantle feeding the hotspot has (partially) preserved a high- ${ }^{37} \mathrm{Cl}$ signature of the primitive mantle. This discrepancy in interpretation is thus open for further research. The observations from Pinti et al. [11] may be confirmed by ${ }^{3} \mathrm{He} /{ }^{4} \mathrm{He}$ and $\delta^{37} \mathrm{Cl}$ data from Northern Portuguese mineral waters [18,19]. Although the highest measured $\mathrm{R} / \mathrm{Ra}(2.7)$ and $\delta^{37} \mathrm{Cl}(+0.31 \%)$ values presented in studies $[18,19]$ are considerably lower than the highest data observed by Pinti et al. [11], when the trend is extrapolated to an $\mathrm{R} / \mathrm{Ra}$ of 8 indeed the predicted $8^{37} \mathrm{Cl}$ is about $+0.9 \%$. As the geothermal water samples from Pinti et al. [11] were taken from a continental area in Mexico, they possibly represent better the $\delta^{37} \mathrm{Cl}$ of the lithospheric mantle, just like in the study by Marques et al. [19]. Both studies are applied to continental areas in either Mexico or Portugal and share comparable positive $\delta^{37} \mathrm{Cl}$ values. As the Mexican data [11] suggest that $\delta^{81} \mathrm{Br}$ values are of the same order of magnitude as $\delta^{37} \mathrm{Cl}$ values, it is suggested that, in other regions, $\delta^{81} \mathrm{Br}$ should also be comparable. However, as no $\delta^{81} \mathrm{Br}$ of any mantle derived material has ever been measured, this suggestion could not be confirmed yet.

These relatively high estimates for the mantle [11] are based on the measurement of deep geothermal waters, and not from solid material. In the present study, we present the first ever $\mathrm{Br}$ isotope data from $\mathrm{Br}$-rich minerals that crystallised from magmas ultimately derived from the lithospheric mantle. The $\delta^{81} \mathrm{Br}$ values obtained from these measurements may indicate whether the value suggested earlier [11] can be a reasonable estimation of lithospheric mantle or not.

The only minerals that are known to have been analysed for their Br isotope compositions are evaporite salt minerals. This includes halite, which has very low $\mathrm{Br}$ contents [20]. Only in some mantle-derived alkaline rocks a magmatic to hydrothermal $\mathrm{Cl}$-rich mineral (sodalite, $\mathrm{Na}_{8} \mathrm{Al}_{6} \mathrm{Si}_{6} \mathrm{O}_{24} \mathrm{Cl}_{2}$ ) with sufficiently high $\mathrm{Br}$ contents is abundant. A structurally similar mineral (tugtupite, $\mathrm{Na}_{8} \mathrm{Be}_{2} \mathrm{Al}_{2} \mathrm{Si}_{8} \mathrm{O}_{24} \mathrm{Cl}_{2}$ ) crystallises under hydrothermal condi- 
tions only. The Br contents in these minerals vary between 25 and $150 \mu \mathrm{g} / \mathrm{g}$ [21]. Thus, 0.15 to $1 \mathrm{~g}$ of mineral separate is sufficient for $\mathrm{Br}$ isotope analysis [5], so that these minerals are a valid target for the determination of $\mathrm{Br}$ isotopes in magmatic rocks and hydrothermal systems.

\section{Material}

Samples used in this study derive from the Ilímaussaq Intrusion (South Greenland), which is one of the most evolved peralkaline intrusions known and contains large quantities of the $\mathrm{Cl}$ rich minerals sodalite and eudialyte [22]. For this study, we used previously characterized magmatic and hydrothermal sodalite and hydrothermal tugtupite samples [21]. Magmatic sodalites derive from coarse-grained plutonic rocks that contain abundant euhedral sodalite (up to 70 vol.\%) and interstitial alkali feldspar, nepheline, amphibole, and eudialyte. Hydrothermal sodalite and tugtupite samples derive from late-stage cm- to $\mathrm{dm}$-wide veins that crosscut the magmatic rocks and contain variable amounts of sodalite, nepheline, albite, amphibole, and zeolithes [22].

For our study, we selected magmatic sodalite samples with $\mathrm{Br}$ concentrations between 100 and $150 \mu \mathrm{g} / \mathrm{g}$, and hydrothermal sodalite and tugtupite samples with Br concentrations between 50 and $100 \mu \mathrm{g} / \mathrm{g}$. This difference was made, because no more sample material than about $500 \mathrm{mg}$ could be collected from magmatic sodalite. For this reason, magmatic sodalite samples with Br concentrations lower than $100 \mu \mathrm{g} / \mathrm{g}$ could not be measured. From hydrothermal sodalite and tugtupite, larger sample amounts were available so that $1 \mathrm{~g}$ of sample, necessary to measure the $\delta^{81} \mathrm{Br}$ value, could be collected.

\section{Methods}

Sodalite and tugtupite are both soluble in diluted nitric acid. For that reason, the technique developed by Eggenkamp and Louvat [5] was chosen to extract Br from the samples. An amount of mineral separate sufficient to collect enough $\mathrm{Br}$ for isotope analysis was ground in a mortar and subsequently weighed. The ground mineral was put in a 50-mL two-neck round-bottom flask to which $8 \mathrm{~mL}$ Milli-Q water (18.2 M $\Omega$ ) and $2 \mathrm{~mL}$ concentrated nitric acid was added, as well as a few Teflon anti bumping granules to facilitate gentle boiling. The distillation set-up was assembled as described before [5] and consisted of a bridge and a 5-mL plastic vial containing $1 \mathrm{~mL}$ of a $0.5 \mathrm{M} \mathrm{NH}_{3}$ solution as ammonium trap. The sample was gently heated using a Teclu-burner until boiling. The mineral dissolved and bromide present was dissolved in and oxidised to $\mathrm{Br}_{2}$ by the nitric acid. The $\mathrm{Br}_{2}$ was distilled to the ammonia trap. In this trap, the $\mathrm{Br}_{2}$ was reduced to bromide. A small amount of nitrate was also distilled resulting in a bromide containing ammonium nitrate $\left(\mathrm{NH}_{4} \mathrm{NO}_{3}\right)$ solution that is ideal to measure $\delta^{81} \mathrm{Br}$ by ICP-MS [4]. The principle of the $\mathrm{Br}$ isotope measurements is described in detail in a prior study [4]. Samples were measured on a Thermo Neptune MC-ICP-MS instrument, which is a double-focusing high-resolution magnetic sector field instrument with an argon inductively coupled plasma and multicollection on nine mobile Faraday cups. Samples were introduced to the mass spectrometer through a small $20-\mathrm{mL}$ cyclonic spray chamber with a $50-\mu \mathrm{L} / \mathrm{min}$ PFA nebuliser. Measurements were performed in low resolution mode. Instrumental mass bias was corrected by sample-standard bracketing. To reduce the memory effect of $\mathrm{Br}$ in the introduction system, all $\mathrm{Br}$ solutions were prepared with $\mathrm{NH}_{4} \mathrm{NO}_{3}$ at $0.2 \mathrm{M}$. The $\delta^{81} \mathrm{Br}$ measurements were carried out in triplicate for each sample (Std-Smpl-Std-Smpl-StdSmpl-Std) and reported with an error of two standard deviations. The bracketing standard solutions are prepared to the same $\mathrm{Br}$ and $\mathrm{Cl}$ concentrations as the analysed samples, to avoid linearity bias and matrix effects. Using this set-up, the internal reproducibility (2SD) over five $\delta^{81} \mathrm{Br}$ determinations for each sample is usually better than $\pm 0.15 \%$.

The Br contents in the original mineral separates were determined by ion-chromatography on the $\mathrm{NH}_{4} \mathrm{NO}_{3}$ solutions and calculated back to the amount of mineral separate used for Br extraction. 


\section{Results}

Br concentrations and $\delta^{81} \mathrm{Br}$ values change systematically between the three sample types (Table 1, Figure 1). $\delta^{81} \mathrm{Br}$ values are lowest in magmatic sodalite samples, slightly higher in hydrothermal sodalite samples, and significantly higher in the (hydrothermal) tugtupite samples. Br concentrations are highest in the magmatic sodalite samples and are lower in hydrothermal sodalite samples, and even lower in tugtupite samples. Hydrothermal sodalite sample ILM127 has a $\delta^{81} \mathrm{Br}$ value that is different compared to the other hydrothermal sodalite samples and more in line with that for tugtupite. $\mathrm{Br}$ concentrations measured after $\mathrm{HNO}_{3}$ extraction were like those measured after $\mathrm{WO}_{3}$ combustion (Table 1), except for magmatic sodalite, where they seem to be higher by a factor of about 1.2. These differences are probably an extraction artefact. As the analytical data obtained by the two extraction methods are comparable, we use the data published in our recent study [21] in the discussions throughout, to maintain consistency between the two studies.

Table 1. Results of the $\mathrm{Br}$ determinations and $\delta^{81} \mathrm{Br}$ measurements of the sodalite and tugtupite samples measured in this study, based on ion-chromatography after $\mathrm{HNO}_{3}$ extraction. Data in the row after the names of the sample groups are averages \pm the standard deviations of the $\mathrm{Br}^{-}$and $\delta^{81} \mathrm{Br}$ values of all samples within each sample group.

\begin{tabular}{|c|c|c|c|}
\hline Sample & $\mathrm{Br}^{-}(\mu \mathrm{g} / \mathrm{g})[21]$ & $\begin{array}{l}\mathrm{Br}^{-}(\mu \mathrm{g} / \mathrm{g}) \\
\text { This Study }\end{array}$ & $\delta^{81} \mathrm{Br}(\%$ vs. SMOB) \\
\hline Magmatic sodalite & $\operatorname{Avg}=138 \pm 10$ & Avg $=172 \pm 21$ & Avg $=0.23 \pm 0.07$ \\
\hline 2016-73 & 122 & 159 & $0.29 \pm 0.11$ \\
\hline 2016-78 & 146 & 178 & $0.15 \pm 0.11$ \\
\hline $2016-85$ & 135 & 148 & $0.24 \pm 0.04$ \\
\hline $2016-87$ & 148 & 173 & $0.16 \pm 0.06$ \\
\hline 2016-96 & 140 & 204 & $0.31 \pm 0.04$ \\
\hline Hydrothermal sodalite & $\operatorname{Avg}=53 \pm 10$ & $\operatorname{Avg}=49 \pm 8$ & $\operatorname{Avg}=0.36 \pm 0.08$ \\
\hline ILM123 & 55.3 & 53.4 & $0.32 \pm 0.12$ \\
\hline ILM138 & 45.0 & 57.2 & $0.45 \pm 0.06$ \\
\hline ILM158 & 44.1 & 36.2 & $0.26 \pm 0.15$ \\
\hline ILM162 & 50.8 & 48.8 & $0.33 \pm 0.08$ \\
\hline GM1246 & 68.3 & 49.4 & $0.43 \pm 0.05$ \\
\hline Tugtupite (hydrothermal) & $\operatorname{Avg}=26 \pm 2$ & $\operatorname{Avg}=34 \pm 8$ & $\operatorname{Avg}=0.71 \pm 0.17$ \\
\hline KK1 & 27.7 & 39.7 & $0.59 \pm 0.09$ \\
\hline KV1 & 24.8 & 28.6 & $0.83 \pm 0.03$ \\
\hline ILM127 (hydrothermal sod.) & & $\operatorname{Avg}=24 \pm 2$ & $\operatorname{Avg}=0.82 \pm 0.12$ \\
\hline$(1)$ & & 25.8 & $0.69 \pm 0.47$ \\
\hline$(2)$ & $47.7 \pm 9.2$ & 22.2 & $0.85 \pm 0.27$ \\
\hline (3) & & 24.1 & $0.92 \pm 0.10$ \\
\hline
\end{tabular}




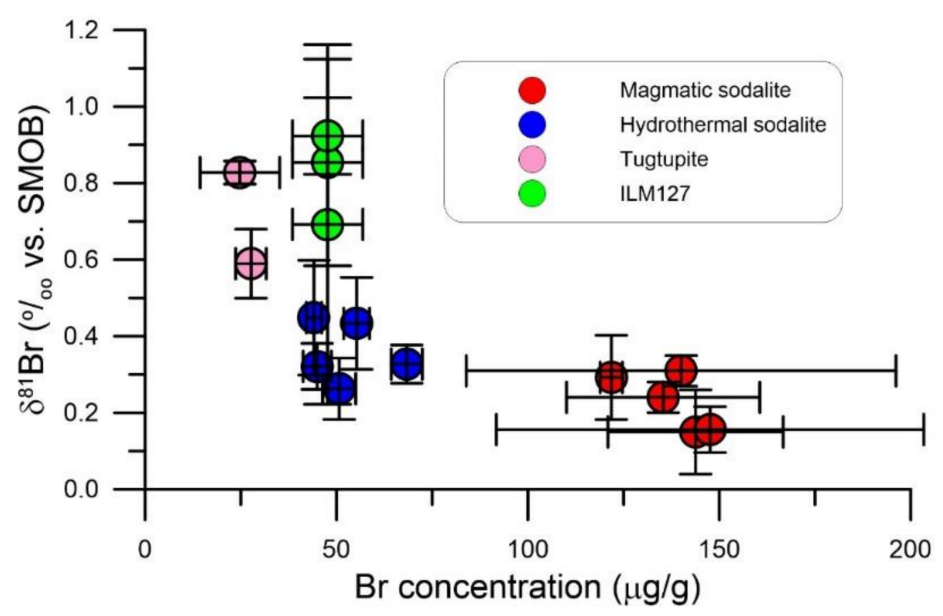

Figure 1. Relationship between the $\mathrm{Br}$ content and the $\delta^{81} \mathrm{Br}$ of the sodalite and tugtupite samples measured in this study. Minerals crystallised at later stages have lower Br concentrations and higher $\delta^{81} \mathrm{Br}$ values.

\section{Discussion}

No $\mathrm{Br}$ isotope values of silicate minerals had been published before. Only from evaporite minerals $\mathrm{Br}$ isotope measurements are available, and these reflect the $\mathrm{Br}$ isotope evolution of individual sedimentary basins or geological periods [20]. Based on these data, it was concluded that the $\mathrm{Br}$ isotope compositions of the oceans was, at most, slightly higher (probably 0 to $+0.25 \%$ vs. SMOB) than today's value and did not change significantly during most of the Earth's history. This suggests that long term Br isotope fractionation between the surface reservoirs (mostly ocean water) and upper mantle reservoirs through the process of subduction is negligible.

$\mathrm{Br}$ isotope values and $\mathrm{Br}$ concentrations are summarised in Figure 1. $\delta^{81} \mathrm{Br}$ values of the magmatic sodalites in our sample set are between 0.15 and $0.31 \%$ with an average value of $0.23 \pm 0.07 \%$. Magmatic sodalite in the Ilímaussaq intrusion crystallised from the final differentiation stage of the magma [21].

In general, $\mathrm{Cl}$ and $\mathrm{Br}$ concentrate in evolving magmatic systems as both elements are incompatible in most minerals during magmatic differentiation. Depending on the redox state of the magma, halogens either concentrate in aqueous fluids (oxidising conditions) as they are strongly soluble in water, or they concentrate in the melt (reducing conditions), when fluids mostly consist of methane, in which halogens are largely insoluble [23]. Under the latter conditions (that apply for llímaussaq [22]), Cl-rich silicate minerals, such as sodalite group minerals (SGM; with up to $7 \mathrm{wt} . \% \mathrm{Cl}$ ) and eudialyte group minerals (EGM, with up to $1.5 \mathrm{wt} . \% \mathrm{Cl}$ ), may form. These two mineral groups host most $\mathrm{Cl}$ and $\mathrm{Br}$ that was present in the melt, as the two elements show very similar behaviour in magmatic processes [24]. Importantly, SGMs take up Br preferentially compared to EGMs [21]. It is assumed that $\mathrm{Br}$ concentrates in the final melt from which SGMs (in principle sodalite proper) crystallise, as it is generally assumed that little $\mathrm{Br}$ is removed from the melt before sodalite crystallises. Still, changes in Br contents and isotope composition will reflect processes such as melt extraction, interaction with asthenosphere melts, interaction with subducted materials, and degassing $[17,25-27]$. The average $\delta^{81} \mathrm{Br}$ in the magmatic sodalite samples is $+0.23 \%$. While this $\delta^{81} \mathrm{Br}$ value is representative for the parental melt, it is not the same, as, during crystallisation, isotope fractionation takes place.

In the case of $\mathrm{Cl}$, sodalite-melt isotope fractionation has been estimated in experimental and theoretical studies [12,28-30]. Equilibrium isotope fractionation of $\mathrm{Cl}$ between sodalite and various other phases, such as liquid $\mathrm{NaCl}$, gaseous $\mathrm{HCl}$, hydrated $\mathrm{Cl}$ ion, and other $\mathrm{Cl}$-bearing minerals invariably points to lower ${ }^{37} \mathrm{Cl}$ values in sodalite as compared to the other phases. Although sodalite-chloride fractionation factors determined in these studies varied significantly depending on phase and temperature they suggest that $\delta^{37} \mathrm{Cl}$ 
of sodalite is in the order of $0.3 \%$ lower than the phase it is in equilibrium with, and we suggest that this is also a reasonable approximation of the equilibrium fractionation between sodalite and the melt from which it is in equilibrium.

Recently, a study was published [10] that described theoretical calculations of $\mathrm{Br}$ isotope fractionation factors mostly for evaporite minerals. The results obtained from the calculations suggest only small fractionation factors between salt and brine and results suggest lower fractionation factors than obtained in earlier experimental studies [31]. Calculated data on $\mathrm{Br}$ doped $\mathrm{Cl}$ minerals suggest that $\mathrm{Br}$ isotope fractionation factors in these minerals are larger than those for pure $\mathrm{Br}$ minerals. This agrees with $\mathrm{Br}$ isotope measurements in natural evaporite systems [32,33].

$\mathrm{Br}$ isotope fractionation in naturally occurring evaporite minerals in equilibrium with salt-saturated aqueous solutions is similar to or slightly larger than $\mathrm{Cl}$ isotope fractionation $[32,33]$. Salt-water fractionation and silicate-melt fractionation are basically similar processes as in both processes two phases are present, one in which $\mathrm{Cl}$ is present as freely moving $\mathrm{Cl}$ ion (with or without a hydration shell) and one in which $\mathrm{Cl}$ is bound in a crystal lattice. Assuming that the isotope fractionation effect between saturated solution and salt can be applied (or be approximated) to sodalite in equilibrium with melt too, $\mathrm{Br}$ isotope fractionation between crystal and melt can be estimated as $-0.3 \%$, which indicates that $\delta^{81} \mathrm{Br}$ of the melt is about +0.5 to $+0.6 \%$, which would, if the melt is representative for the lithospheric mantle, represent a possible lithospheric mantle value. This value agrees well with the value of $+0.7 \%$ as suggested by Pinti et al. [11].

We are cautious in suggesting that a value obtained this way is representative for the lithospheric mantle. Although the melt from which sodalite crystallised is sourced from the lithospheric mantle, the composition of the residual melt may have been changed considerable before the first sodalite crystallises from this melt. Furthermore, considering the related element $\mathrm{Cl}$, it is shown [17] that not only do the $\delta^{37} \mathrm{Cl}$ of the various mantle reservoirs show large variations, but also that variations within individual reservoirs can be significant. As a result, a single datapoint cannot be used to define the (average) value of the (lithospheric) mantle. This is also applicable to $\mathrm{Br}$ isotopes. As our value is in line with that from Pinti et al. [11], it is reasonable to conclude that $\delta^{81} \mathrm{Br}$ values between +0.5 and +0.7 are within the lithospheric mantle range. It is clear however, that more $\mathrm{Br}$ isotope research on mantle material is necessary to start to understand the $\delta^{81} \mathrm{Br}$ distribution in the mantle.

While magmatic sodalite crystallises at temperatures between 650 and $825^{\circ} \mathrm{C}$ [34], hydrothermal sodalite crystallises at temperatures down to about $400^{\circ} \mathrm{C}$ and hydrothermal tugtupite at even lower temperatures, but only when Be concentrations are sufficiently high [35].

During cooling, the Ilímaussaq magma became more reducing until a temperature of about $700{ }^{\circ} \mathrm{C}$, after which the oxygen fugacity rose again [36]. Below a temperature of about $550{ }^{\circ} \mathrm{C}$, the oxidation stage was high enough to facilitate the exsolution of $\mathrm{Cl}$-rich and water-dominated magmatic fluid [37]. Although the magma had solidified at this point, reactions between dissolved $\mathrm{Cl}$ and nepheline produced hydrothermal sodalite to temperatures down to about $400{ }^{\circ} \mathrm{C}$. If Be concentrations were high enough, tugtupite also formed at temperatures below about $500{ }^{\circ} \mathrm{C}$ down to temperatures even lower than those for sodalite [36].

$\delta^{81} \mathrm{Br}$ of hydrothermal sodalite is higher than $\delta^{81} \mathrm{Br}$ of magmatic sodalite ( +0.36 vs. $+0.23 \%$, Figure 1), while the $\mathrm{Br}$ content is significantly less. In tugtupite, the average $\delta^{81} \mathrm{Br}$ is even higher at $+0.71 \%$ and the $\mathrm{Br}$ concentration is lower than in hydrothermal sodalite. This suggests that more $\mathrm{Br}$ is preferentially incorporated in sodalite and thus removed from the fluid phase during crystallisation of sodalite. As the $\delta^{81} \mathrm{Br}$ of the mineral phases increase during evolution from magmatic to hydrothermal sodalite and to tugtupite, this suggests that the light isotope $\left({ }^{79} \mathrm{Br}\right)$ is preferentially removed from the fluid by this process. As the lighter isotope is removed from the fluid, its residual $\delta^{81} \mathrm{Br}$ increases, so that, assuming a fractionation factor that only slowly increases towards lower 
temperatures, later crystallising sodalite becomes isotopically heavier. This confirms the suggestion made above that $\mathrm{Br}$ isotope fractionation is negative during crystallisation of sodalite and tugtupite from its coexisting fluid, something that is schematically shown in Figure 2. As isotope fractionation factors increase towards lower temperatures, the $\mathrm{Br}$ isotope fractionation factor also increases during this process, and we suggest that its value might increase to -0.4 to $-0.5 \%$ in the latest stage when tugtupite crystallises. It is very important, however, that future experimental and theoretical studies will focus on the determination of the actual fractionation factors at different temperatures for both magmatic and hydrothermal processes.

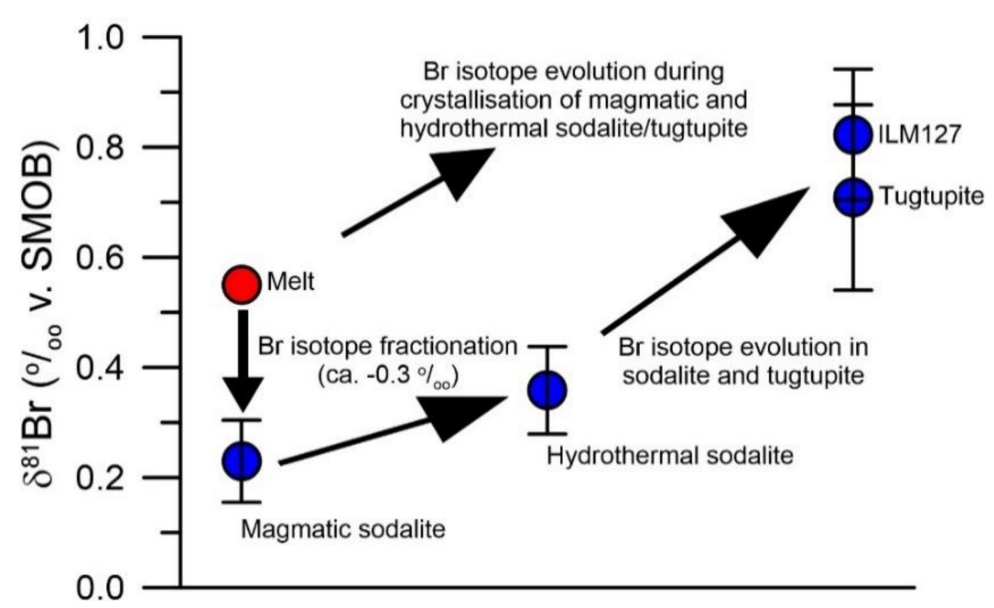

Figure 2. Schematic view of $\mathrm{Br}$ isotope evolution from magmatic sodalite, via hydrothermal sodalite to tugtupite (and ILM127). The lithospheric mantle from which the Ilímaussaq melt was sourced has a value of +0.5 to $0.6 \%$, from which magmatic sodalite crystallised with a fractionation factor of about $-0.3 \%$, giving it the average measured $\delta^{81} \mathrm{Br}$ of $+0.23 \%$. Because light ${ }^{79} \mathrm{Br}$ is preferentially removed from the fluid phases, the $\delta^{81} \mathrm{Br}$ of the residue increases, which leads to higher $\delta^{81} \mathrm{Br}$ values in sodalite that later crystallised. This evolution continues to the last stages resulting in tugtupite (and perhaps sodalite from fluids that do not contain enough $\mathrm{Br}$ to crystallise tugtupite from) with the highest $\delta^{81} \mathrm{Br}$ values.

Sample ILM127 is a hydrothermal sodalite and is used as internal standard in our laboratory. For that reason, this sample has been analysed three times to test the quality and integrity of the $\mathrm{Br}$ isotope measurements. The three measurements confirm the high $\delta^{81} \mathrm{Br}$ of this sample. The $\delta^{81} \mathrm{Br}$ of this sample compares well to the $\delta^{81} \mathrm{Br}$ of the tugtupite samples. This suggests that ILM127 is a highly evolved sodalite sample that crystallised from a fluid that, due to a low Be concentration, has not been crystallised as tugtupite. However, as it crystallised from the last and coolest hydrothermal stage, it has the same $\mathrm{Br}$ isotope characteristics as tugtupite. This scenario might exist at temperatures of around $400{ }^{\circ} \mathrm{C}[36]$.

\section{Conclusions}

We measured $\delta^{81} \mathrm{Br}$ for the first time from magmatic and hydrothermal minerals (sodalite and tugtupite). The data obtained allow us for the first time to suggest values for the $\mathrm{Br}$ isotope fractionation between melt and sodalite. This fractionation can be constrained based on the evolution from magmatic sodalite to hydrothermal sodalite and tugtupite. During this evolution, $\delta^{81} \mathrm{Br}$ of the mineral phases increases, suggesting a negative fractionation factor. $\delta^{81} \mathrm{Br}$ values obtained in this study and comparisons with recent studies on $\mathrm{Cl}$ and $\mathrm{Br}$ isotope fractionation suggest that fractionation factors of about $-0.3 \%$ for fractionation between melt and magmatic sodalite, and possibly -0.4 to $-0.5 \%$ o for fractionation between fluid and hydrothermal minerals at lower temperatures can be constrained. Based on an average $\delta^{81} \mathrm{Br}$ of $+0.23 \%$ for magmatic sodalite, the $\delta^{81} \mathrm{Br}$ of the melt is between +0.5 and $+0.6 \%$. This value is similar to a value of $+0.7 \%$, as 
obtained by Pinti et al. [10]. This suggests that $\delta^{81} \mathrm{Br}$ values between +0.5 and +0.7 are within the lithospheric mantle range. Just like is the case for $\mathrm{Cl}$ isotope variations, it must be realised that the actual $\mathrm{Br}$ isotope range of mantle materials can be considerable and significant further research is necessary to define the range of $\delta^{81} \mathrm{Br}$ variations, not only for the lithospheric mantle, but also the various other mantle reservoirs.

The evolution from magmatic to hydrothermal sodalite and to tugtupite at ever lower temperatures results in continuously decreasing $\mathrm{Br}$ concentrations in the subsequent minerals and continuously increasing $\delta^{81} \mathrm{Br}$ values. This indicates that $\mathrm{Br}$ is depleted in the residual fluid and that (lighter) ${ }^{79} \mathrm{Br}$ is incorporated preferentially in the minerals. This results in increasing $\delta^{81} \mathrm{Br}$ values in subsequently crystallising minerals and implies that $\mathrm{Br}$ isotope fractionation is negative in both magmatic and hydrothermal processes.

Author Contributions: Conceptualization: H.G.M.E. and M.A.W.M.; methodology: H.G.M.E. and M.A.W.M.; analysis: P.L.; validation: P.L.; investigation: H.G.M.E., M.A.W.M., P.L., and G.M.; resources, M.A.W.M., and G.M.; writing-original draft preparation, H.G.M.E. and M.A.W.M.; writing-review and editing, H.G.M.E., M.A.W.M., P.L., and G.M.; project administration, M.A.W.M.; funding acquisition, M.A.W.M. All authors have read and agreed to the published version of the manuscript.

Funding: This research was funded by the German Research Council (DFG) under grant no. MA256313. Part of this work was supported by IPGP multidisciplinary program PARI and Region Île-deFrance SESAME Grant no. 12015908.

Data Availability Statement: All data collected for and used in this study is contained within the article in Table 1 and ref. [21].

Acknowledgments: Individual sodalite and tugtupite samples were hand-picked by student assistants Aylin Polat, Laura Paskert, Isabel Antony, Sarah Fieger, Brian-Eric Friedrichsen, and Yannick Wolfhard. We would like to thank two anonymous reviewers as well as the scientific editor of this special issue for their constructive reviews of this manuscript.

Conflicts of Interest: The authors declare no conflict of interest. The funders had no role in the design of the study; in the collection, analyses, or interpretation of data; in the writing of the manuscript, or in the decision to publish the results.

\section{References}

1. Eggenkamp, H.G.M.; Coleman, M.L. Rediscovery of classical methods and their application to the measurement of stable bromine isotopes in natural samples. Chem. Geol. 2000, 167, 393-402. [CrossRef]

2. Eggenkamp, H.G.M. The Geochemistry of Stable Chlorine and Bromine Isotopes; Springer: Berlin/Heidelberg, Germany, 2014; 172p.

3. Shouakar-Stash, O.; Alexeev, S.V.; Frape, S.K.; Alexeeva, L.P.; Drimmie, R.J. Geochemistry and stable isotopic signatures, including chlorine and bromine isotopes, of the deep groundwaters of the Siberian Platform, Russia. Appl. Geochem. 2007, 22, 589-605. [CrossRef]

4. Louvat, P.; Bonifacie, M.; Giunta, T.; Michel, A.; Coleman, M. Determination of Bromine stable isotope ratios from saline solutions by "wet plasma" MC-ICPMS including a comparison between high- and low-resolution modes, and three introduction systems. Anal. Chem. 2016, 88, 3891-3898. [CrossRef] [PubMed]

5. Eggenkamp, H.G.M.; Louvat, P. A simple distillation technique to extract bromine for MC-ICP-MS isotope analyses. Rapid Comm. Mass Spectrom. 2018, 32, 612-618. [CrossRef]

6. McKinney, C.R.; McCrea, J.M.; Epstein, S.; Allen, H.A.; Urey, H.C. Improvements in mass spectrometers for the measurement of small differences in isotope abundance ratios. Rev. Sci. Instr. 1950, 21, 724-730. [CrossRef]

7. Du, Y.; Ma, T.; Yang, J.; Liu, L.; Shan, H.M.; Cai, H.S.; Liu, C.F.; Chen, L.Z. A precise analytical method for bromine stable isotopes in natural waters by GasBench II-IRMS. Int. J. Mass Spectrom. 2013, 338, 50-56. [CrossRef]

8. Godon, A.; Jendrzejewski, N.; Eggenkamp, H.G.M.; Banks, D.A.; Ader, M.; Coleman, M.L.; Pineau, F. A cross calibration of chlorine isotopic measurements and suitability of seawater as the international reference material. Chem. Geol. 2004, $207,1-12$. [CrossRef]

9. Kaufmann, R.S. Chlorine in Groundwater. Stable Isotope Distribution. Ph.D. Thesis, University of Arizona, Tucson, AZ, USA, 1984.

10. Gao, C.H.; Liu, Y. First-principles calculations of equilibrium bromine isotope fractionations. Geochim. Cosmochim. Acta 2021, 297, 65-81. [CrossRef] 
11. Pinti, D.L.; Shouakar-Stash, O.; Castro, M.C.; Lopez-Hernandez, A.; Hall, C.M.; Rocher, O.; Shibata, T.; Ramirez-Montez, M. The bromine and chlorine isotopic composition of the mantle as revealed by deep geothermal fluids. Geochim. Comochim. Acta 2020, 276, 14-30. [CrossRef]

12. Sharp, Z.D.; Barnes, J.D.; Brearley, A.J.; Chaussidon, M.; Fischer, T.P.; Kamenetsky, V.S. Chlorine isotope homogeneity of the mantle, crust and carbonaceous chondrites. Nature 2007, 446, 1062-1065. [CrossRef]

13. Sharp, Z.D.; Mercer, J.A.; Jones, R.H.; Brearley, A.J.; Selverstone, J.; Bekker, A.; Stachel, T. The chlorine isotope composition of chondrites and Earth. Geochim. Cosmochim. Acta 2013, 107, 189-204. [CrossRef]

14. Bonifacie, M.; Jendrzejewski, N.; Agrinier, P.; Humler, E.; Coleman, M.; Javoy, M. The chlorine isotope composition of Earth's mantle. Science 2008, 319, 1518-1520. [CrossRef]

15. Layne, G.D.; Kent, A.J.R.; Bach, W. ${ }^{37} \mathrm{Cl}$ systematics of a back-arc spreading system: The Lau Basin. Geology 2009, 37, 427-430. [CrossRef]

16. John, T.; Layne, G.D.; Haase, K.M.; Barnes, J.D. Chlorine isotope evidence for crustal recycling into the mantle. Earth Planet. Sci. Lett. 2010, 298, 175-182. [CrossRef]

17. Hoare, B.C.; Tomlinson, E.L.; Barnes, J.D.; Tappe, S.; Marks, M.A.W.; Epp, T.; Caufield, J.; Riegler, T. Tracking halogen recycling and volatile loss in kimberlite magmatism from Greenland: Evidence from combined $\mathrm{F}-\mathrm{Cl}-\mathrm{Br}$ and $\delta^{37} \mathrm{Cl}$ systematics. Lithos 2021, 384-385, 105976. [CrossRef]

18. Carreira, P.M.; Marques, J.M.; Carvalho, M.R.; Capasso, G.; Grassa, F. Mantle-derived carbon in Hercynian granites. Stable isotopes signatures and C/He associations in the thermomineral waters, N-Portugal. J. Volcanol. Geotherm. Res. 2010, 189, 49-56. [CrossRef]

19. Marques, J.M.; Eggenkamp, H.G.M.; Carreira, P.M.; da Silva, M.A. Origin and evolution of $\mathrm{Cl}$ in the CO2-rich thermal and mineral waters from Northern Portugal, based on a reinterpretation of its chemical and isotope characteristics. Appl. Geochem. 2020, 116, 104569. [CrossRef]

20. Eggenkamp, H.G.M.; Louvat, P.; Agrinier, P.; Bonifacie, M.; Bekker, A.; Krupenik, V.; Griffioen, J.; Horita, J.; Brocks, J.J.; Bagheri, R. The bromine and chlorine isotope composition of primary halite deposits and their significance for the secular isotope composition of seawater. Geochim. Cosmochim. Acta 2019, 264, 13-29. [CrossRef]

21. Eggenkamp, H.G.M.; Marks, M.A.W.; Atanasova, P.; Wenzel, T.; Markl, G. Changes in halogen (F, Cl, Br, and I) and S ratios in rock-forming minerals as monitors for magmatic differentiation, volatile loss, and hydrothermal overprint: The case for peralkaline systems. Minerals 2020, 10, 995. [CrossRef]

22. Marks, M.A.W.; Markl, G. The Ilímaussaq alkaline complex, South Greenland. In Layered Intrusions; Charlier, B., Namur, O., Latypov, R., Tegner, C., Eds.; Springer Geology; Springer: Dordrecht, The Netherlands, 2015; pp. 649-691.

23. Marks, M.A.W.; Markl, G. A global review on agpaitic rocks. Earth Sci. Rev. 2017, 173, 229-258. [CrossRef]

24. Bureau, H.; Métrich, N. An experimental study of bromine behaviour in water-saturated silicic melts. Geochim. Cosmochim. Acta 2003, 67, 1689-1697. [CrossRef]

25. Bureau, H.; Foy, E.; Raepsaet, C.; Somogyi, A.; Munsch, P.; Simon, G.; Kubsky, S. Bromine cycle in subduction zones through in situ $\mathrm{Br}$ monitoring in diamond anvil cells. Geochim. Cosmochim. Acta 2010, 74, 3839-3850. [CrossRef]

26. Cochain, B.; Sanloup, S.; de Grouchy, C.; Crépisson, C.; Bureau, H.; Leroy, C.; Kantor, I.; Irifune, T. Bromine speciation in hydrous silicate melts at high pressure. Chem. Geol. 2015, 404, 18-26. [CrossRef]

27. Cadoux, A.; Iacono-Marziano, G.; Scaillet, B.; Aiuppa, A.; Mather, T.A.; Pyle, D.M.; Deloule, E.; Gennaro, E.; Paonita, A. The role of melt composition on aqueous fluid vs. silicate melt partitioning of bromine in magmas. Earth Planet. Sci. Lett. 2018, 498 , 450-463. [CrossRef]

28. Schauble, E.; Sharp, Z.D. Modeling isotopic signatures of nebular chlorine condensation. Min. Mag. 2011, 75, 1810.

29. Balan, E.; Créon, L.; Sanloup, C.; Aléon, J.; Blanchard, M.; Paulatto, L.; Bureau, H. First-principles modeling of chlorine isotope fractionation between chloride bearing molecules and minerals. Chem. Geol. 2019, 525, 424-434. [CrossRef]

30. Czarnacki, M.; Hałas, S. Isotope fractionation in aqua-gas systems: $\mathrm{Cl}_{2}-\mathrm{HCl}-\mathrm{Cl}^{-}, \mathrm{Br}_{2}-\mathrm{HBr}_{-} \mathrm{Br}^{-}$and $\mathrm{H}_{2} \mathrm{~S}-\mathrm{S}^{2-}$. Isot. Environ . Health Stud. 2012, 48, 55-64. [CrossRef]

31. Eggenkamp, H.G.M.; Bonifacie, M.; Ader, M.; Agrinier, P. Experimental determination of stable chlorine and bromine isotope fractionation during precipitation of salt from a saturated solution. Chem. Geol. 2016, 433, 46-56. [CrossRef]

32. Eggenkamp, H.G.M.; Louvat, P.; Agrinier, P. Halogen stable isotope evolution during experimental evaporation of seawater type brines. In Proceedings of the ESIR Workshop XV, Lublin, Poland, 23-27 June 2019.

33. Eggenkamp, H.G.M.; Louvat, P.; Griffioen, J.; Agrinier, P. Chlorine and bromine isotope evolution within a fully developed Upper Permian natural salt sequence. Geochim. Cosmochim. Acta 2019, 245, 316-326. [CrossRef]

34. Giehl, C.; Marks, M.A.W.; Nowak, M. An experimental study on the influence of fluorine and chlorine on phase relations in peralkaline phonolitic melts. Contrib. Mineral. Petrol. 2014, 167, 977. [CrossRef]

35. Markl, G. Stability of Na-Be minerals in late-magmatic fluids of the Ilímaussaq alkaline complex, South Greenland. Geol. Greenl. Surv. Bull. 2001, 190, 145-158. [CrossRef]

36. Markl, G.; Marks, M.; Schwinn, G.; Sommer, H. Phase equilibrium constraints on intensive crystallization parameters of the Ilímaussaq Complex, South Greenland. J. Petrol. 2001, 42, 2231-2258. [CrossRef]

37. Graser, G.; Potter, J.; Köhler, J.; Markl, G. Isotope, major, minor and trace element geochemistry of late-magmatic fluids in the peralkaline Ilímaussaq intrusion, South Greenland. Lithos 2008, 106, 207-221. [CrossRef] 